\title{
IMPLEMENTSI PEMANFAATAN MEDIA TEKA TEKI SILANG (TTS) ONLINE DALAM MATAKULIAH NEUROSAINS UNTUK MAHASISWA CALON GURU RAUDHATUL ATHFAL
}

\author{
Sri Maryanti \\ Universitas Islam Negeri Sunan Gunung Jati Bandung \\ Email: sri.mayanti@uinsgd.ac.id \\ Dede Trie Kurniawan \\ Universitas Swadaya Gunung Jati Cirebon
}

Artikel Diterima: 30 April 2017 Proses Review Artikel: 24 September 2017

Artikel Diterbitkan: 30 September 2017

\begin{abstract}
ABSTRAK
Penelitian ini bertujuan untuk mendeskripsikan penggunaan aplikasi teka teki silang (TTS) secara Online untuk calon guru raudhatul athfal (RA) Universitas Islam Negeri Sunan Gunung Djati Bandung. Fokus dari kajian ini yaitu untuk mendeskripsikan respon mahasiswa calon guru RA terhadap penggunaan TTS Online. Aplikasi TTS dibuat melalui software Eplicse Crossword dan diintegrasikan secara online melalui http://bumibiologi.weebly.com/neurosains.html. Mahasiswa calon guru raudhatul athfal yang dimaksud adalah mahasiswa semester 4 yang mengontrak mata kuliah neurosains semester genap 2016-2017. Mata kuliah neurosains ini merupakan ilmu neural yang mempelajari system saraf, terutama mempelajari neuron atau sel saraf dengan pendekatan multidisipliner. Teknik pengumpulan data yang dilakukan yaitu : 1. Observasi langsung, 2. Angket, 3. Analisis dokumen 4. Tes Berbentuk TTS. Berdasarkan data dan analisis hasil yang dilakukan pada dua kelas yaitu kelas A dan kelas B maka diperoleh temuan penelitian bahwa TTS Online dapat meningkatkan ketertarikan mahasiswa calon guru RA terhadap mata kuliah neurosains. Mahasiswa Memberikan respon bahwa penggunaan TTS Online ini sangat bermanfaat bagi perkuliahan mereka. Penggunan TTS Online ini di rasakan mudah dan tepat dalam perkuliahan neurosains. Mahasiswa menilai salah satu penggunaan teknik perkulihan dengan TTS Online ini sudah baik dalam penerapannya.
\end{abstract}

Kata kunci : TTS Online, Neurosains, calon guru, RA 


\section{PENDAHULUAN}

Secara psikologis, hakikat Pendidikan merupakan seluruh optimalisasi potensi yang dimiliki oleh manusia. Potensi yang dimiliki manusia bertumpu pada otaknya. Ilmu yang mempelajari otak adalah neurosains (Paisak, 2006). Secara etimologi, neurosains adalah ilmu saraf (neural science) yang mempelajari system saraf, terutama mempelajari neuron atau sel saraf dengan pendekatan multidisipliner (Paisak, 2012). Pada dasarnya neurosains merupakan cabang ilmu biologi yang kemudian berkembang pesat bahkan berintegrasi dengan berbagai disiplin ilmu lain, seperti psikologi (neurosains kognitif atau neuro-psikologi), biokimia, fisiologi, farmakologi, informatika, ilmu computer, statistika, fisika, dan kedokteran.

Otak merupakan bagian dari tumpuan seluruh potensi manusia. Oleh Karena itu, Pendidikan harus berintegrasi dengan neurosains. Pendidikan Anak Usia Dini (PAUD) adalah salah satu bentuk institusi atau lembaga Pendidikan yang harus memasukan neurosains ke dalam pembelajarannya (Suyadi, 2015). Tujuan utama dari ilmu ini adalah mempelajari dasar-dasar biologis dari setiap perilaku. Artinya, tugas utama dari neurosains adalah menjelaskan perilaku manusia dari sudut pandang aktivitas yang terjadi di dalam otaknya. Semua system dalam otak bekerja secara terpadu untuk membangun sikap dan perilaku manusia. Dosen perlu menentukan metode perkuliahan yang tepat untuk bisa menyampaikan perkuliahan sesuai dengan tujuan utama yang telah ditentukan.

Pemilihan metode perkuliahan yang tepat pastinya akan meningkatkan keberhasilan proses perkuliahan. Belajar adalah proses usaha yang dilakukan seseorang untuk memperoleh suatu perubahan tingkah laku yang baru secara keseluruhan. Keberhasilan perkuliahan bergantung pada beberapa faktor, yaitu 1) faktor internal ialah faktor yang berasal dari dalam mahasiswa itu sendiri. 2) faktor eksternal ialah faktor yang berasal dari luar mahasiswa. Faktor internal meliputi bahan belajar, motivasi, sikap, perasaan, emosi dan intelegensi. Sedangkan faktor eksternal meliputi bahan pelajaran, metode mengajar, media dan lingkungan baik didalam kelas maupun diluar kelas. Mahasiswa calon guru RA tidak banyak yang memiliki latar belakang dari pendidikan IPA saat sekolah dijenjang SMA/Ma, maka perlu sebuah strategi pembelajaran dan metode yang tepat dalam memberikan perkuliahan neurosains. Strategi perkuliahan dengan menggunakan teka teki silang dan di integrasikan dengan pemanfaatan internet dianggap cocok untuk menanggulangi hal ini. 
Untuk mengatasi masaalah perkuliahan diatas diperlukan sebuah strategi dan metode perkuliahan yang tidak harus menghafalkan fakta - fakta, tetapi strategi yang mendorong mahasiswa mengkonstruksikan pengetahuan dibenak mereka sendiri. Penggunaan media pembelajaran sangat membantu dosen mengembangkan dan memperdalam proses belajar mengajar di perkuliahan. Penggunaan media yang bervariasi dengan tepat dapat mempengaruhi prestasi belajar. Salah satunya digunakan media permainan teka teki silang yang diintegrasikan secara online dengan domain weebly.com.

Teka teki silang (TTS) merupakan permainan bahasa dengan cara mengisi kotak kotak dengan huruf - huruf sehingga membentuk kata yang dapat dibaca, baik secara vertikal maupun horizontal. Dengan TTS ini dapat memberikan pemahaman terhadap materi secara mudah dan mendalam. Menyusun tes TTS ini akan mengundang partisipasi dan minat dari mahasiswa. Teka-teki silang sebagai teknik pembelajaran kosakata tentu lebih menarik karena mengandung unsur permainan, hiburan dan dapat dilakukan secara santai dengan berbagai variasi. Dengan demikian, mahasiswa termotivasi dan bergairah mempelajari kosakata yang dapat merangsang daya nalarnya untuk memahami materi, sehingga dapat mudah diingat dan menjadi pengetahuan yang sangat berkesan dan tidak mudah dilupakan sebagai sebuah pengalaman belajar. Akibatnya dapat memberi pemahaman terhadap materi secara mudah dan mendalam. Namun demikian tidaklah mudah untuk membuat TTS. Akan tetapi banyak keuntungan dari penggunaan media ini diantaranya adalah dapat meningkatkan motivasi mahasiswa dalam menjawab soal karena terdapat unsur permainan, meningkatkan kerja sama yang sehat antar mahasiswa, merangsang mahasiswa untuk berpikir kritis dan kreatif, memacu mahasiswa untuk lebih teliti dalam mengerjakan soal. Adapun Bentuk TTS yang digunakan dan Software pembuat TTS ini dapat disajikan pada gambar 1 berikut ini. 


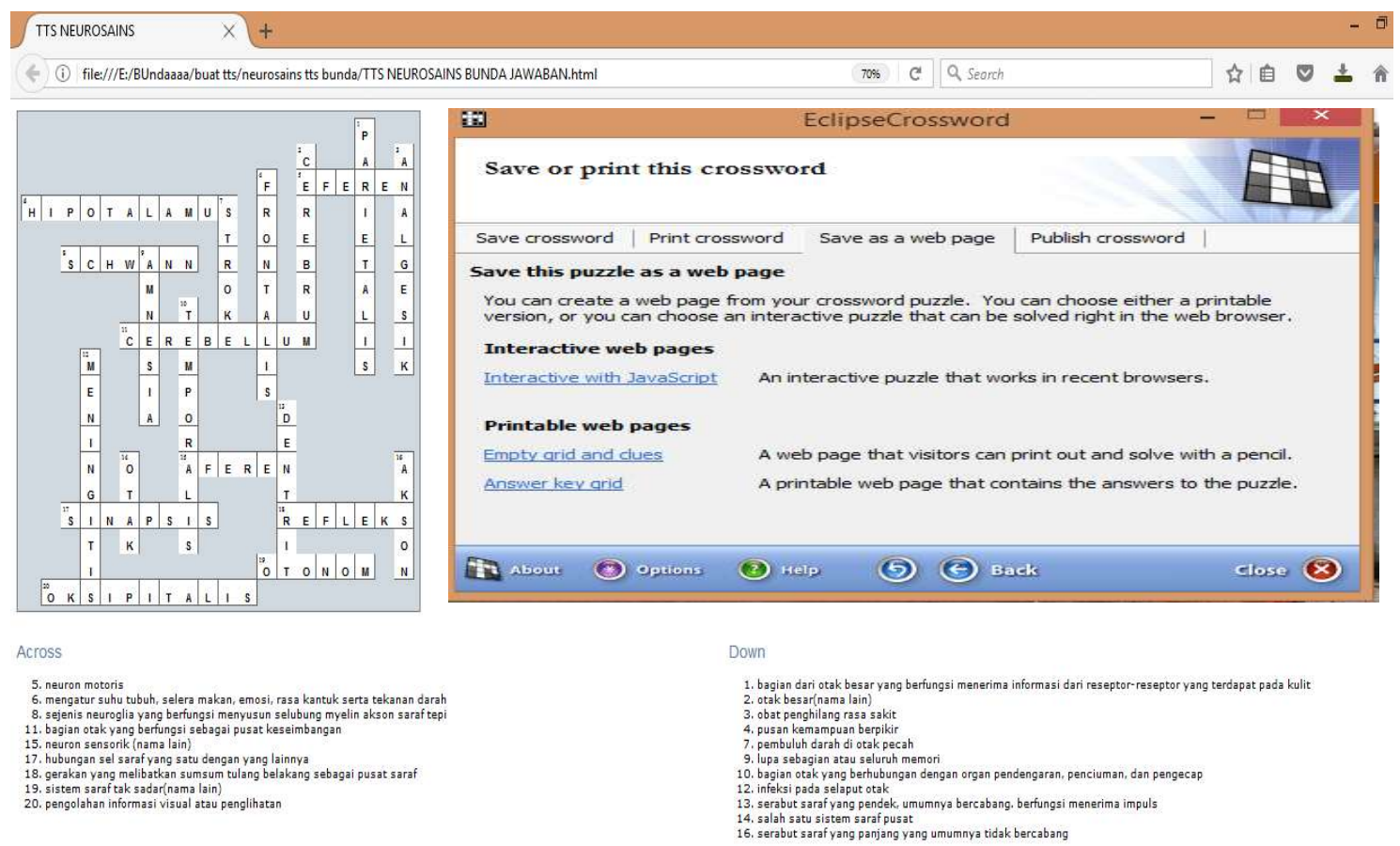

Gambar 1. Teka Teki Silang Hasil Program Eclipse Crossword

Di era teknologi informasi ini dan dengan pesatnya perkembangan teknologi komputer/gadget saat ini, manfaat komputer telah dirasakan di berbagai sektor kehidupan salah satunya di bidang pendidikan. Sebagai contoh, dengan adanya komputer/ gadget multimedia yang mampu menampilkan gambar maupun teks yang diam dan bergerak (animasi) serta bersuara sudah saatnya untuk dapat dijadikan sebagai salah satu alternatif pilihan media pembelajaran yang efektif. Salah satu manfaat komputer/ gadget sebagai media bagi dosen adalah sebagai alat bantu dalam menyiapkan bahan ajar dan dalam proses pembelajarannya sendiri. Berdasarkan hal tersebut, Calon guru RA seharusnya mengetahui manfaat komputer/gadget sehingga tergerak untuk menggunakannya sebagai salah satu media pembelajaran.

Adapun Produk Teka teki silang ini diintegrasikan dengan website interaktif untuk pembelajaran di www.weeebly.com . Tujuanya agar dapat diakses kapan saja, dimana saja dan mudah digunakan oleh mahasiswa melalui smartphonenya. Dengan Menghasilkan produk bahan ajar digitalberupa TTS Online yang diberikan kepada mahasiswa calon guru RA, dosen memfasilitasi dan membangun ruang pengerjaan proyek tersebut dalam perkuliahannya, 
sehingga mahasiswa dapat berkonsultasi akan masalah penyelesaian jawaban TTS yang dikerjakannya.

Berdasarkan latar belakang yang telah dikemukan, peneliti tertarik untuk mengadakan penelitian mengenai Implementasi Pemanfaatan Media Teka Teki Silang (TTS) Online dalam matakulah neurosains untuk mahasiswa calon guru raudhatul anfal (RA) disalah satu Universitas Islam negeri Kota Bandung.

\section{BAHAN DAN METODE}

Jenis penelitian ini bersifat deskriptif yaitu pemecahan masalah yang diselidiki dengan mengambarkan atau melukiskan keadaan obyek penelitian pada saat sekarang berdasarkan fakta-fakta yang tampak atau sebagaimana adanya. Menurut Nazir metode deskriptif adalah suatu metode dalam meneliti status sekelompok manusia suatu objek, suatu set kondisi, suatu system pemikiran ataupun suatu kelas peristiwa pada masa sekarang. Metode yang digunakan dalam penelitian ini adalah metode pendekatan survei. Karena dalam penelitian ini pengumpulan data pokok melalui kuesioner yang diambil dari sampel suatu populasi. Hal ini sejalan dengan penelitian yang akan dilakukan dengan teknik pengumpulan data yaitu : observasi langsung, analisis dokumen serta Tes berbentuk TTS.

Penelitian dilakukan pada mahasiswa yang mengontrak matakuliah neursoains pada tahun perkuliahan 2016/2017. Subyek penelitian adalah sumber utama data penelitian, yaitu yang memiliki data mengenai variabel-variabel yang diteliti. Subyek penelitian pada dasarnya, adalah yang akan dikenai kesimpulan hasil penelitian Terkait dengan penelitian ini subyek penelitiannya adalah pemakai atau mahasiswa semester 4 yang mengontrak mata kuliah neurosains yang dikelompokkan menjadi kelas A dan kelas B.

Dalam penelitian ini, langkah-langkah yang dilakukan dapat dibagi menjadi tiga tahap, yaitu tahap pra-penelitian, tahap pelaksanaan, dan tahap pasca penelitian. Rincian kegiatan yang dilakukan pada setiap tahap adalah sebagai berikut:

1. Tahap pra-penelitian

a. Penentuan kelas yang akan dijadikan subjek studi lapangan.

b. Persiapan instrumen studi lapangan, misalnya penyusunan format lembar observasi dan angket. 
c. Persiapan Media TTS melalui program eclipse crosword yang dintegrasikan dengan weebly.com

\section{Tahap Pelaksanaan}

Pengambilan data berdasarkan identifikasi masalah, diantaranya adalah:

a. Observasi proses pembelajaran, Fasilitas dan sarana prasarana Pembelajaran

b. Pemberian angket pada mahasiswa untuk mengetahui dominansi kecerdasan majemuk mahasiswa calon guru RA

c. Tes berdasarkan hasil TTS Baik secara Manual maupun Online

3. Tahap akhir

a. Pengembangan teori berdasarkan analisis data yang diperoleh

b. Evaluasi Implementasi Pemanfatan media TTS Online

Secara umum, kegiatan penelitian ini dapat dilihat pada alur penelitian di bawah ini :

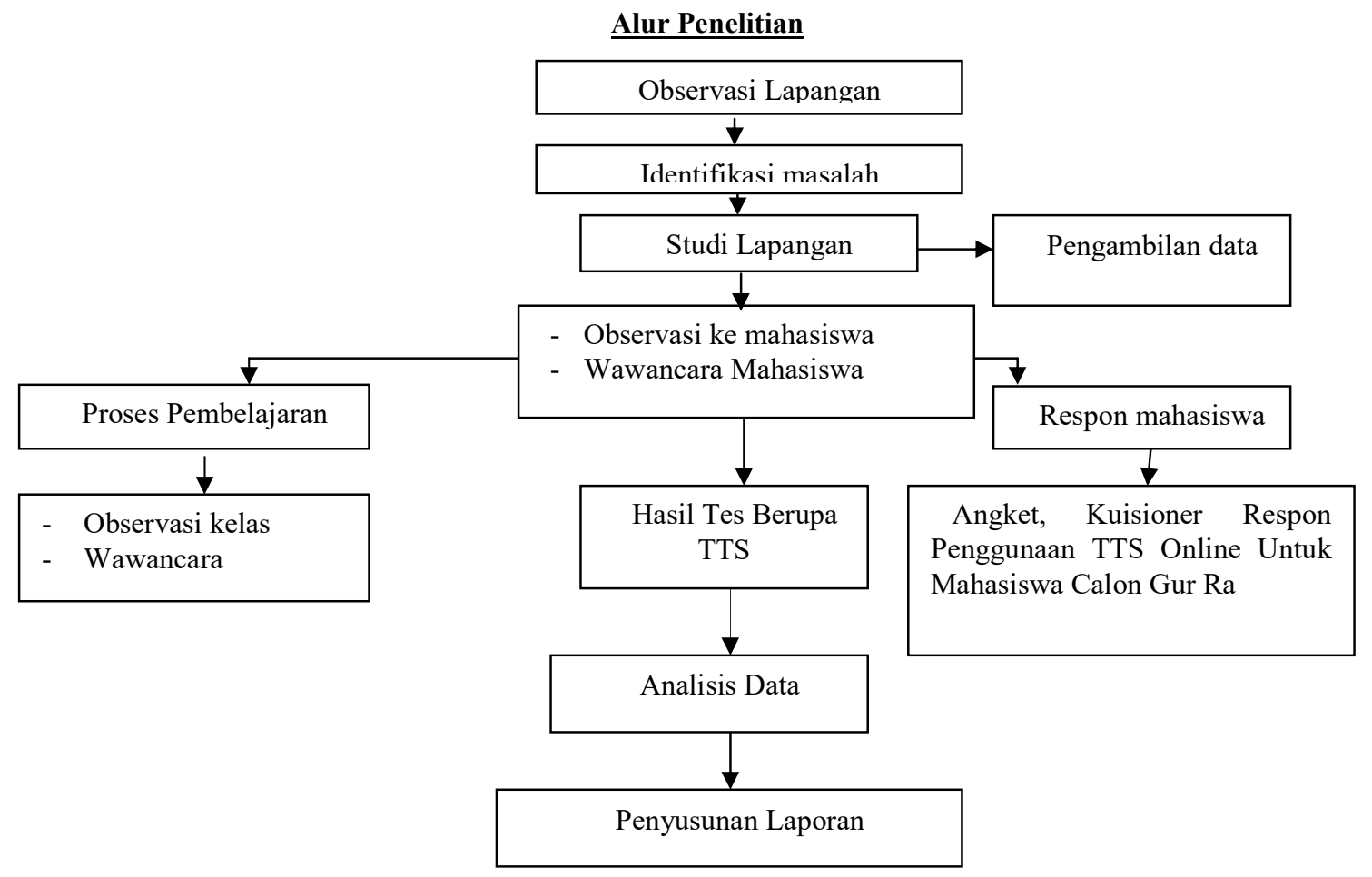

\section{HASIL DAN PEMBAHASAN}

Hasil Penelitian berupa produk media Teka teki siang yang diintegrasikan secara online melalui domain weebly.com, Respon mahasiswa mengenai penggunaan TTS Online 
dan Hasil Tes TTS Online mahasiswa calon guru Ra disalah satu Universitas islam negeri Kota Bandung.

\section{A. Produk Media Teka - Teki Silang Online}

Teka Teki Silang (TTS) merupakan media pembelajaran yang berfungsi sebagai alternatife latihan soal dan dapat juga digunakan sebagai alat evaluasi untuk materi neurosains. Latihan soal - soal neurosains dalam bentuk TTS lebih mendorong rasa ingin tahun mahasiswa. Pengembangan Teka Teki silang ini menggunakan Software Eclipse Crossword dan didukung dengan penambahan informasi - informasi neurosains mengenai materi yang bersangkutan. TTS Neurosains ini disajikan menarik dan didasain belajar dalam kondisi yang tenang dan menyenangkan. Teka Teki Silang dapat mendorong mahasiswa beajar mandiri yaitu, mahasiswa mencari tahu sendiri jawaban soal - soal yang disediakan serta siswa dapat mengembangkan pengetahuannya. Untuk menudukung kemandirian belajar mahasiswa, TTS ini di Integrasikan dengan website weebly.com. Adapun alamat Webiste yang dituju untuk mengakses TTS Online Neurosains ini adalah http://bumibiologi.weebly.com/neurosains.html . Dengan Diintegrasikan dengan website ini mahasiswa dapat mengaksesnya kapan saja dan diaman saja melalui laptop ataupun smartphonenya. Disamping Menampilkan TTS Online di webiste ini juga disajikan menu obrolan dan pengisisan kuisioner secara online.Tampilan TTS Online disajikan pada gambar 3 berikut ini. 


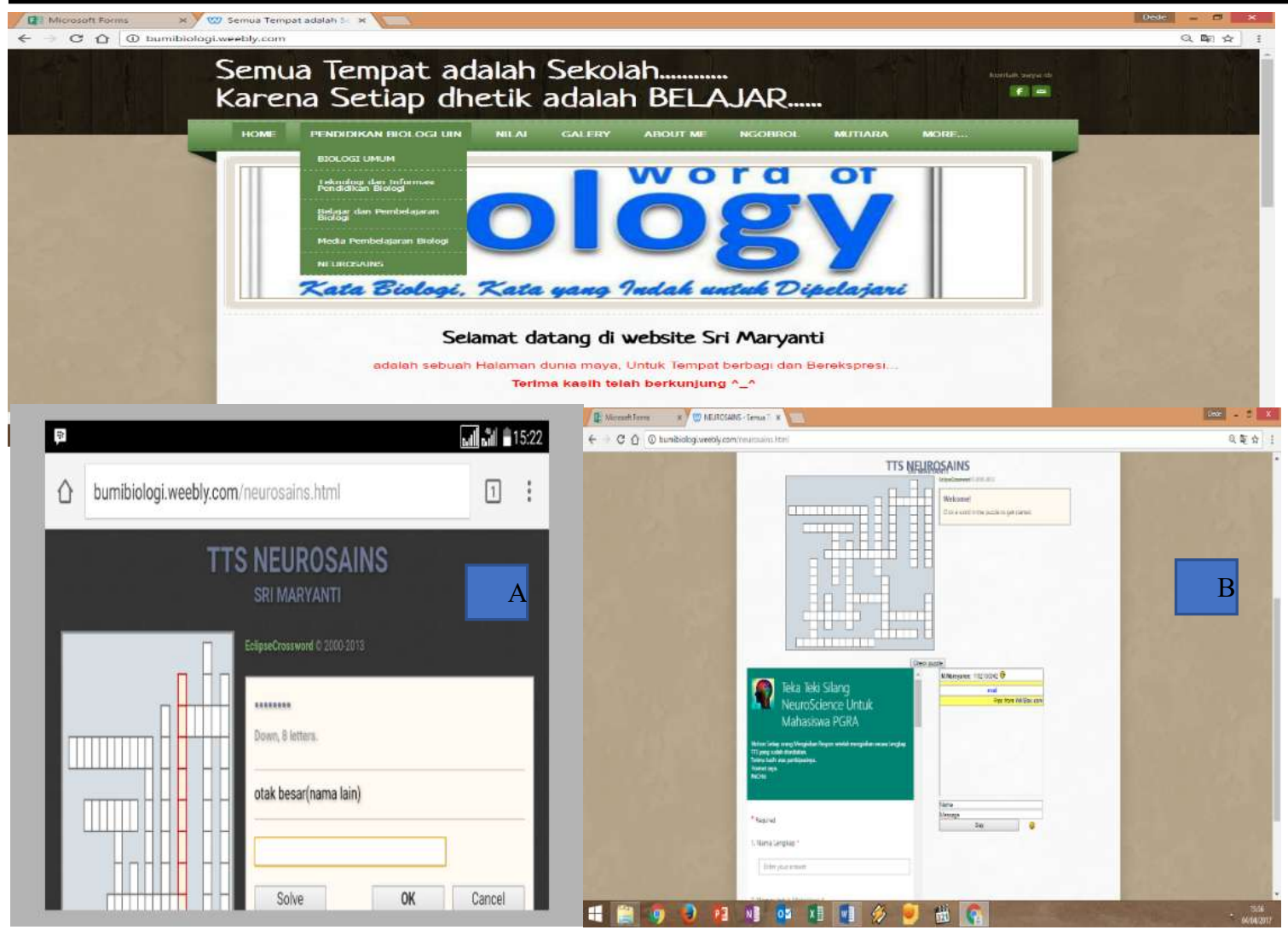

Gambar 3. Teka Teki Silang Online di domain weebly.dom (http://bumibiologi.weebly.com/neurosains.html.) A. Diakses Melalui Smartphone B. Diakses Melaui Komputer/Laptop

\section{B. Respon Mahasiswa Terhadap Penggunaan Teka Teki Silang Online}

Data respon mahasiswa terhadap implementasi penggunanaan TTS Online pada matakuliah neurosains dipeoleh dari kuisioner yang dibagikan ke semua mahasiswa calon guru Ra Tingkat 2 peserta matakuiah neurosains dengan dosen Sri Maryanti, S.Si., M.Pd. Kuisioner ini bersifat Online dan disajikan dalam satu halaman Webiste berdampingan dengan TTS Online. Adapun Aplikasi pembuat kuisioner online ini menggunakan Microsft Form. 
Teka Teki Silang Neuroscience Untuk Mahasiswa PGRA

68

4. Menurut Anda Perkuliahan dengan TTS dan Aplikasi On Line ini di beri Rating Berapa? (1 Bintang Tidak Baik, 5 Bintang Sangat Baik)

\section{Responses}

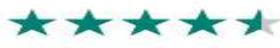

6. Apakah Penggunaan TTS Online ini bermanfaat bagi anda

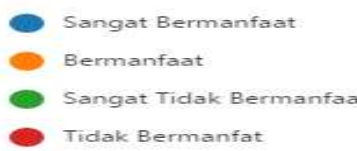

46
18
3
0

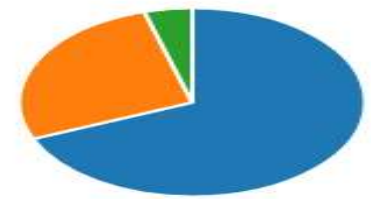

7. Apakah TTS Online Ini Mudah Untuk anda pahami prosedurnya?
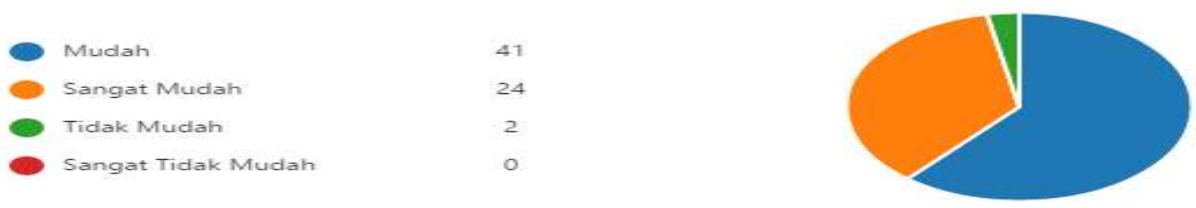

8. Apakah Penjelasan Dosen Dapat diterima oleh anda mengenai prosedur penggunan TTS Online
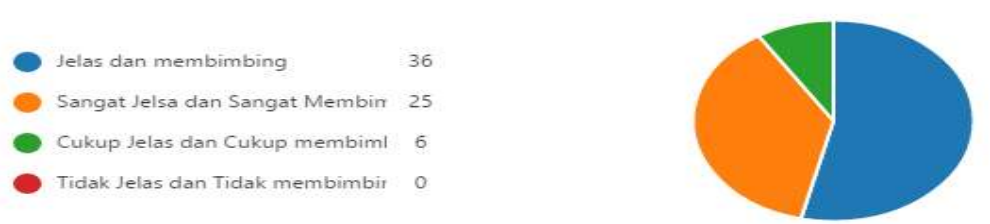

Details

9. Pendekatan dan metode perkuliahan dengan TTS Online ini menurut anda
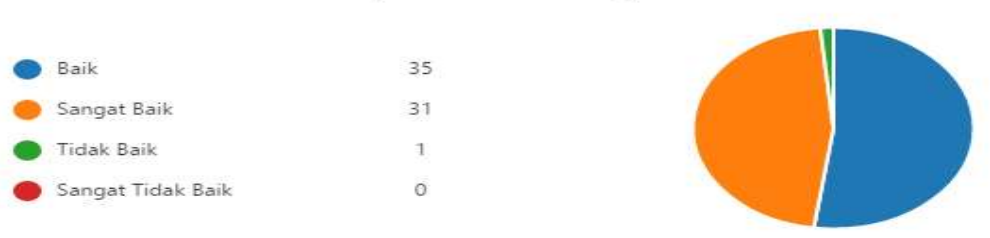

Gambar 4. Respon Mahasiswa Terhadap Implementasi TTS Online dalam perkuliahan Neurosains Untuk mahasiswa calon gur RA 


\section{Hasil Pencapaian Latihan Mandiri TTS Online}

Penyajian 20 soal latihan mandiri dalam bentuk TTS Online ini dikerjakan dalam rentang waktu teretntu oleh mahasiswa sebagai tugas mandiri. Untuk Hasil pencapaian Berupa Pengisian TTS Online sebagai bentuk latihan soal mandiri dapat disajikan pada gambar 5 berikut ini.

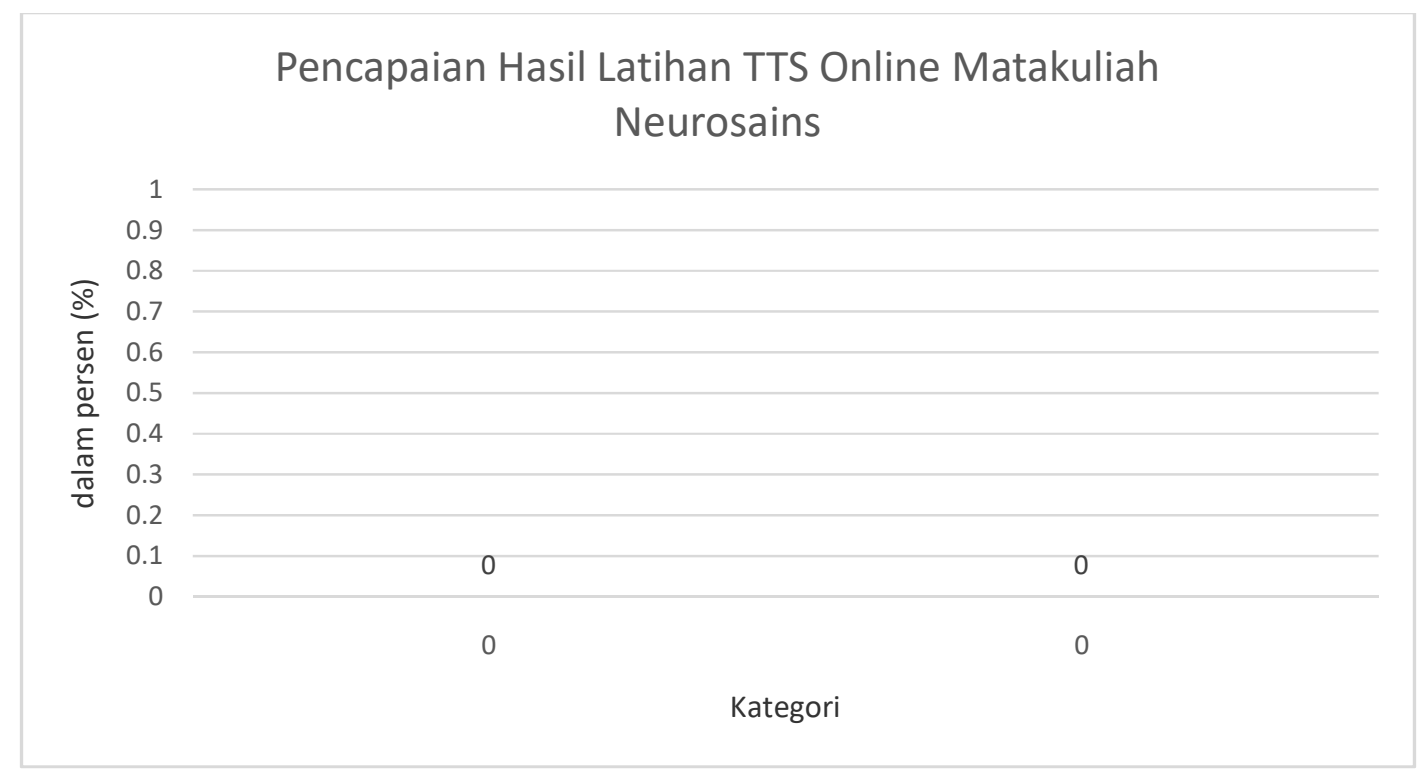

Gambar 5. Data Hasil Pencapaian Latihan Mandiri TTS Online Mahasiswa Calon Guru Ra pada matakuliah neurosains

Dari data di atas dapat dilihat bahwa kelas A memiliki nilai 64,3 sedangkan untuk kelas B lebih rendah satu angka yaitu dengan nilai 63,4. Berikut disajikan beberapa komentar mahasiswa yang terangkum dalam kuisioner yang dibagikan kepada mahasiswa untuk mengetahui bagaimana respon mereka mengenai implementasi TTS Online pada matakuliah neurosains untuk mahasiswa calon guru Ra.

Tabel 1. Respon Mahasiswa terhadap Implementasi TTS Online di Matakuliah Neurosains untuk calon Guru RA

\begin{tabular}{|c|l|}
\hline Kelas & \multicolumn{1}{|c|}{ Respon Mahasiswa } \\
\hline PIAUD B & $\begin{array}{l}\text { Bagus, Lewat TTS Berbasis Aplikasi Ini, Saya Jadi Bisa Mengerjakannya } \\
\text { Dimana Saja Juga Bisa Bekerjasama. Model TTS Ini Membuat Soal }\end{array}$ \\
\hline
\end{tabular}




\begin{tabular}{|c|c|}
\hline Kelas & Respon Mahasiswa \\
\hline & $\begin{array}{l}\text { Tidak Terlalu Sulit Karena Tidak Menegangkan Dan Jawaban Satu Bisa } \\
\text { Menjadi Kata Kunci Untuk Jawaban Soal Lainnya. Namun, Terjadi } \\
\text { Beberapa Konten Yang Eror Di Web Ini. Seperti Kotak-Kotaknya } \\
\text { Menjadi Satu, Ketika Di Klik Keyboard Smartphone Tidak Muncul } \\
\text { (Malah Jadi Loading), Dan Tidak Keluar Menu Dalam Web Ini. } \\
\text { Terimakasih }\end{array}$ \\
\hline PIAUD-A'15 & $\begin{array}{l}\text { Sangat Menyenangkan Dan Membantu Nilai Mahasiswa Jadi Lebih } \\
\text { Baik:) Aamiin }\end{array}$ \\
\hline PIAUD A & $\begin{array}{l}\text { Kesannya Luarbiasa Beda....Pesannya Di Adain Lagi TTS Online Nya } \\
\text { Karena Sangat Menyenangkan Ternyata. }\end{array}$ \\
\hline A & $\begin{array}{l}\text { Seru, Nambah Ilmu, Mudah Hafal, Pokonya Seneengg Banged !.. } \\
\text { Makasi Ibu :D }\end{array}$ \\
\hline B & $\begin{array}{l}\text { Sangat Menarik. Sebuah Metode Pengajaran Yang Memanfaatkan } \\
\text { Teknologi Berbasis Online Akan Meningkatkan Antusiasme Mahasiswa } \\
\text { Sehingga Dapat Mengikuti Zaman Yang Teknologinya Berkembang } \\
\text { Sangat Canggih Dalam Hal Menuntut Ilmu Dan Menambah Wawasan. }\end{array}$ \\
\hline $\mathrm{A}$ & $\begin{array}{l}\text { Sangat Mengasikan Soalnya Pas Kita Ngisi Teka Teki Silang Walaupun } \\
\text { Soalnya Mendebarkan Tapi Enjoy Ketika Mengisinya Serasa Main Game } \\
\text { Aja }\end{array}$ \\
\hline PIAUD IV/B & Menyenangkan \& Bermanfaat, Bisa Jadi Inspirasi Hehe \\
\hline PIAUD-A & Menjadikan Kita Tetep Melek Didalam Tekhnologi \\
\hline $\begin{array}{l}\text { PIAUD-B/ } \\
2015\end{array}$ & Sangat Kreatif Sehingga Kuispun Tidak Membosankan \\
\hline A & $\begin{array}{l}\text { Kesan Pertama Sudah Luarbiasa Asyik,Dimana Kita Mencoba Mengasah } \\
\text { Kognitif Dengan Test Yang Berbeda Dari Yang Lain, Pesan Nya } \\
\text { Pertahankan Bu Greet And Good Banget Pokonya.. Baru Kali Ini Ngisi } \\
\text { TTS Versi Serius.. Hihi }\end{array}$ \\
\hline A & Subhanallah, Alhamdulillah Allahuakbar. Pesannya \\
\hline
\end{tabular}




\begin{tabular}{|c|c|}
\hline Kelas & Respon Mahasiswa \\
\hline & $\begin{array}{l}\text { Pertahankan Terus Ibu Asahan Otak Dengan Cara Yang Berbeda Dari } \\
\text { Yang Lain. Good Job Pokonya Buat Ibu Sri }\end{array}$ \\
\hline PIAUD A & $\begin{array}{l}\text { Baru Pertama Kali Ngisi Soal Online Dan Rasanya Lebih Santai Tapi } \\
\text { Sambil Belajar Juga Jadi Rame Buuu }\end{array}$ \\
\hline PIAUD A & $\begin{array}{l}\text { Sebelumnya Belum Pernah Mengisi Soal Online. Tapi Begitu Diberikan } \\
\text { Tugas Oleh Ibu Dan Online Ternyata Lebih Rame Dan Lebih Santai Dan } \\
\text { Tidak Menegangkan Bu Hehehe }\end{array}$ \\
\hline PIAUD/B/IV & Belajar Sambil Bermain Itu Memang Menyenangkan.. \\
\hline PIAUD IV-B & $\begin{array}{l}\text { Membuat Asik, Mebuat Betah Untuk Terus Belajar, TTS Online Serasa } \\
\text { Belajar Sambil Bermain Dan Selalu Ingin Ngisi Ttsnya Terus Menerus =) } \\
\text { Dan Jangan Bosan Bosan Untuk Membuat TTS Online Nya Ibu Ku Ter } \\
\text { Cinta =) }\end{array}$ \\
\hline PIAUD/IV/B & Sangat Menarik, Bermanfaat Sekali Bu $\square$ \\
\hline PIAUD-B & $\begin{array}{l}\text { Kesan: Sangat Menarik Dan Menguji Konsentrasi Pesan: Semoga Kuis } \\
\text { Online Tts Ini Tetap Ada Sampai Kapanpun.. }\end{array}$ \\
\hline PIAUD IV A & Menyenangkan \\
\hline Piaud VI A & $\begin{array}{l}\text { Menantang Pokonamah Seru Bu Terimakasih Haha, Semoga Bermanfaat } \\
\text { Bagi Kalian Semua Rekan Rekan Angkatan Semester VI Yang } \\
\text { Terhormat, Khususnya Bagi Nanti Semester Semsester Selanjutnya Yang } \\
\text { Akan Mempelajari Tentang Mata Kuliah Neurosains Ini. Hatur Nuhun }\end{array}$ \\
\hline PIAUD-A & $\begin{array}{l}\text { Seru Karna Sangat Jarang Sekali Matakuliah Menyediakan TTS Berbasis } \\
\text { Online }\end{array}$ \\
\hline PIAUD B & $\begin{array}{l}\text { Lebih Memudahkan Dalam Pengisian TTS.. Setidaknya Ada Bocoran } \\
\text { Meskipun Satu Huruf.. Hhi. Tau Jawaban Yg Kmaren Engga Di Isi.. }\end{array}$ \\
\hline PIAUD/A & $\begin{array}{l}\text { TTS Nya Luarbiasa Seru, Mendidik, Dan Mengasah Otak. Pesan Nya } \\
\text { Tingkatkan Lagi TTS Selanjutnya }\end{array}$ \\
\hline PIAUD 4A & $\begin{array}{l}\text { Sangat Menarik,Karena Dengan Metode Seperti Ini,Pembelajaran Mudah } \\
\text { Terserap,Tidak Merasa Tertekan Untuk Membaca Materi"Yang Telah }\end{array}$ \\
\hline
\end{tabular}




\begin{tabular}{|l|l|}
\hline \multicolumn{1}{|c|}{ Kelas } & \multicolumn{1}{|c|}{ Respon Mahasiswa } \\
\hline & Dijelaskan Dosen \\
\hline PIAUD A & $\begin{array}{l}\text { Seru, Mungkin Kalau Tugasnya Dalam Bentuk Seperti Ini Lebih } \\
\text { Semangat Lagi Untuk Mengerjakan Tugasnya Soalnya Beda Dari } \\
\end{array}$ \\
\hline Piasanya \\
\hline PIAUD B & Lebih Semangat, Karna Menemukan Sesuatu Yang Unik Dan Baru \\
\hline
\end{tabular}

\section{PEMBAHASAN}

Agar proses pembelajaran itu dapat berjalan secara optimal, maka guru atau pengajar perlu membuat strategi yaitu “ strategi belajar mengajar". Kata strategi sendiri dapat diartikan sebagai suatu rencana kegiatan yang dirancang secara seksama untuk mencapai tujuan yang ditunjang atau didukung oleh hasil pemilihan pengetahuan atau keterampilan yang dikuasai (Rustaman, 2005). Salah satu strategi yang diambil menggunakan aplikasi teka teki silang berbasis online

Teka teki silang atau biasa disebut TTS merupakan permainan klasik. Selain digunakan untuk menghilangkan rasa jenuh. TTS juga bermanfaat untuk mengasah kemampuan otak dan menambah pengetahuan. Menurut dr. Samino, Sp.S.(K), staf pengajar departemen Neurologi Fakultas Kedokteran Universitas Indonesia, untuk melakukan berbagai aktivitas yang merupakan stimulant untuk mencegah turunnya fungsi otak. Salah satu aktivitas tersebut,yaitu dengan mengisi teka-teki silang. Mata kuliah Neurosain bagi calon guru RA merupakan bagian dari mata kuliah sains yang tak lepas dari kosakata atau kata ilmiah sehingga TTS merupakan salah satu cara untuk lebih dapat mengingat kata ilmiah dalam istilah biologi atau neurosains.

Secara tidak langsung TTS juga dapat menguasai kosakata. Kosakata merupakan salah satu unsur Bahasa yang harus dikuasai oleh seorang pembelajar pada umumnya. Tapi mempelajari Bahasa tidak identic dengan mempelajari kosakata. Artinya untuk memiliki kemahiran berbahasa tidak cukup hanya dengan menghafal. Savier (dalam Fries, 1970) menyatakan: " para pembelajar Bahasa tidak bias mengenal Bahasa melalui kamus" 
Secara keseluruhan implementasi penggunaan TTS pada mata kuliah neurosains sangat menarik untuk diterapkan sebagai bahan latihan yang menyenangkan dan mencerdaskan tanpa adanya tekanan atau paksaan sehingga bias dilakukan dengan nyaman. Senada dengan penelitian yang telah dilakukan oleh Laily(2016) bahwa media pembelajaran yang melibatkan TTS memberikan pengaruh positif Karena telah meningkatkan hasil belajar siswa serta memiliki tanggapan yang sangat baik dari siswa yang mengalami pembelajaran tersebut.

\section{DAFTAR PUSTAKA}

Gardner, Howard.2007. Multiple Intelegence.Jakarta: Indek

Hafni Syaeful Sulun dan Rinaldi Munir, Pembangkit TTS dengan Algoritma Backtracking

Serta Aplikasi Permainannya Berbasis Web. Jurnal Informatika Vol 4 no 2, Juli 2010, Institut Teknologi Bandung.

Kurniawan, Dede Trie. 2016. Pengembangan Portofolioelektronik berbasis website dengan domain weebly.com untuk penilaian produk bahan ajar digital mahasiswa calon guru matematika. Laporan Penelitian Internal Dosen Lembaga Penelitian Unswagati Cirebon. Tidak diterbitkan.

Maryanti, Sri.2017. Profil Kecerdasdan Majemuk Mahsiswa calon guru Ra di UIN Sunan Gunung Djati Bandung. Jurnal Pendidikan Raudhatul Anfal FTK UIN SGD Bandung.

Nasir. 2003. Metode Penelitian. Jakarta : Ghalia Indonesia.

Nuryani Rustaman, 2005. Strategi Pembelajaran Biologi. Bandung : Universitas Negeri Malang.

Laily, S. (2016). Pengembangan Media Pembelajaran Kosakata Bahasa Arab Berbasis Permainan Teka Teki Silang pada Siswa MI di Yogjakarta. Skripsi. Yogyakarta: UIN Sunan Kalijaga.

Paisak. Taufiq. 2012. Tuhan dalam Otak Manusia, Mewujudkan Kesehatan Spiritual Berdasarkan Neurosains. Bandung: Mizan

S, Rani Fathonah, Sugihanto, Suryadi Budi Utomo.2013. Studi Komparasi penggunaan media teka - teki silang dengan kartu pada pembelajaran kimia melalui pendekatan CTL terhadap prestasi belajar siswa pada materi zat adiktif dan psikotropika kelas VIII SMP N 2 Ngadirjo, Wonogiri tahun pelajaran 2011-2012. Jurnal Pendidikan Kimia (JPK) Vol 
2. No.3 Tahun 2013. Program Studi Pendidikan kimia Universitas sebelas maret. ISSN 2337-9995

Suyadi, 2015. Teori Pembelajaran Anak Usia Dini dalam Kajian Neurosains. Bandung: Rosda

, 2009. Permainan Edukatif yang Menrdaskan. Yogjakarta :Gara Ilmu 
AWLADY: Jurnal Pendidikan Anak

Homepage: www.syekhnurjati.ac.id/jurnal/index.php/awlady

E-mail: pgrasyekhnurjati@gmail.com

P-ISSN: 2541-4658 